\title{
PENGARUH MOTIVASI KERJA DAN LOYALITAS KERJA TERHADAP PRODUKTIVITAS KERJA KARYAWAN PT. CISARUA MOUNTAIN DAIRY
}

\author{
ADE CHAIRUNNISA ${ }^{1}$, JAENUDIN $^{2}$ \\ Ade.chairunisa@gmail.com¹, jaenudin@ibm.ac.id ${ }^{2}$ \\ Program Studi Manajemen \\ Institut Bisnis Muhammadiyah Bekasi
}

\begin{abstract}
This study aims to determine the effect of work motivation and loyalty on the work productivity of PT. Cimory employees, and the research was conducted directly at the PT. Cimory factory in the Sentul industrial area. This research is a descriPT.ive study with a quantitative approach, the data collection techniques used in this study are questionnaires and direct interviews with related parties according to the research objectives. The research subjects used were employees of PT. Cimory as many as 100 respondents. The analysis technique uses the classical assum PT.ion test, multiple regression with the model feasibility test, namely the $t$ test and $f$ test. The results showed that from 100 respondents it was known that by means of the t test (partial), the variable of work motivation on the work productivity of PT. Cimory employees obtained a significant influence, with a value of $t$ count 4.021> 1.660 t table. As for the job loyalty variable partially there is no significant effect on the work productivity of PT. Cimory employees, with a value of t count $0.462<1.660$ t table. While the $f$ test (simultaneous) work motivation and job loyalty have a significant effect on the work productivity of PT. Cimory employees, with a calculated $f$ value of 8.108> 3.09.
\end{abstract}

Keywords: work motivation, job loyalty, work productivity

\section{A. PENDAHULUAN}

PT. Cisarua Mountain Dairy (PT. Cimory) merupakan salah satu Industri Pengolahan Susu yang terletak di daerah pegunungan Cisarua Kabupaten Bogor, Jawa Barat dengan jumlah pekerja sebanyak 530 karyawan. PT. Cisarua Mountain Dairy (PT. Cimory) didirikan pada tahun 2006 dan merupakan salah satu anak perusahaan MACRO Group, yang bergerak di dalam bidang pangan berbasiskan empat protein alami terbaik yaitu daging yang diproduksi oleh (PT. Macroprima Panganutama), Susu (PT.
Cisarua Mountain Dairy), telur (PT. Java Egg Specialities) dan kacang kedelai (PT. Indosoya Sumber Protein). Perusahaan pengolahan susu ini sangat peduli dengan kehidupan peternak susu di Indonesia. Dalam upaya untuk mengurangi impor susu bubuk serta menaikkan taraf hidup para peternak, PT. Cimory menyerap susu local dengan harga yang sangat baik, Artinya, semua produk yang diproduksi PT. Cimory berbahan susu segar, yang dikelola menjadi minuman yogurt dan susu Ultra High Temperature (UHT) dengan berbagai varian rasa. 
Tabel 1

Jumlah Tenaga Kerja PT. Cimory 2015-2019

\begin{tabular}{|c|c|c|}
\hline No & Tahun & Jumlah Tenaga Kerja \\
\hline 1 & 2015 & 571 \\
\hline 2 & 2016 & 584 \\
\hline 3 & 2017 & 572 \\
\hline 4 & 2018 & 553 \\
\hline 5 & 2019 & 530 \\
\hline
\end{tabular}

Berdasarkan data pada tabel 1.1 yang diperoleh dari perusahaan tersebut, untuk lima tahun belakangan ini mengalami penurunan jumlah karyawan dari tahun 2016. Penurunan jumlah karyawan dari tahun ke tahun disebabkan karena beberapa faktor di antaranya, mengundurkan diri atau menarik diri dari perusahaan karena adanya pekerjaan lain yang lebih menarik, alasan menarik diri karena lingkungan kerja yang ditawarkan lebih baik, ada pula yang pensiun, meninggal dan di-PHK karena tidak mematuhi aturan yang ada di perusahaan. Hal-hal tersebut terkait dengan perencanaan SDM yang kurang baik atau perencanaan yang ada hanya untuk jangka pendek dan tidak berlaku dengan rencana jangka panjang perusahaan.

$$
\text { Berdasarkan pernyataan- }
$$

pernyataan di atas dan didorong untuk mendalami bidang ekonomi khususnya pada konsentrasi manajemen sumber daya manusia yang telah diperoleh di bangku kuliah, maka penulis tertarik mengadakan penelitian dengan judul: "Pengaruh Motivasi Kerja dan Loyalitas Kerja Terhadap Produktivitas Kerja Karyawan PT. Cisarua Mountain Dairy."

\section{B. DASAR-DASAR TEORI}

\section{Pengertian Produktivitas Kerja}

$$
\text { Riyanto (1986:22) menyatakan }
$$

bahwa produktivitas kerja adalah suatu perbandingan antara hasil yang dicapai (output) dengan keseluruhan sumber daya yang diperlukan (input). Produktivitas mengandung pengertian perbandingan antara hasil yang dicapai dengan peran tenaga kerja persatuan waktu.
Edy Sutrisno

(2010:99)

Menyatakan bahwa Produktivitas secara umum diartikan sebagai hubungan antara keluaran (barang-barang atau jasa) dengan masukan (tenaga kerja, bahan, uang). Produktivitas adalah ukuran efisiensi produktif. Suatu perbandingan antar hasil keluaran dan masukan.

Berdasarkan beberapa definisi dapat disimpulkan bahwa produktivitas kerja adalah kemampuan menghasilkan suatu kualitas barang melalui perbandingan antara hasil keluaran dan masukan dengan sumber daya yang diperlukan dalam efisiensi waktu tertentu, dengan indikator sebagai berikut:

1. Kemampuan menghasilkan sesuatu (Kemampuan)

2. Perbandingan antara hasil yang dicapai berdasarkan kualitas yang dihasilkan (Kualitas/Mutu)

3. Sumber daya yang diperlukan (Sumber daya manusia)

4. Volume jangka waktu (Efisiensi)

Faktor-faktor yang mempengaruhi produktivitas kerja

Ada beberapa faktor yang dapat mempengaruhi produktivitas kerja karyawan yaitu:

a. Pendidikan

Tingkat kecerdasan karyawan dilihat dari tingkat pendidikannya. Semakin tinggi pendidikan semakin besar kemungkinan untuk mendapatkan tujuan ke jenjang yang lebih baik.

b. Kesehatan jasmani dan rohani

Salah satu tugas pimpinan perusahaan adalah menjamin kesehatan karyawan yaitu dengan cara mengatur jam kerja, meniadakan lembur sehingga dapat 
menciptakan kegiatan kerja para karyawan.

c. Lingkungan kerja

Lingkungan kerja yang baik akan berpengaruh besar dalam meningkatkan produktivitas.

d. Faktor manajerial

Gaya kepemimpinan yang efektif, memotivasi, mengarahkan, dan menggerakan bawahannya agar dapat bekerja dengan lebih semangat dan bergairah dalam melaksanakan tugas.

e. Motivasi

Pemberian motivasi oleh seseorang pimpinan yang baik akan membimbing dan melatih karyawannya.

f. Peralatan yang digunakan

Peralatan yang digunakan mempunyai efek yang sangat penting dalam meningkatkan produktivitas kerja.

\section{Pengukuran Produktivitas Kerja}

Tingkat produktivitas kerja karyawan yang dapat diukur adalah:

a. Penggunaan waktu

b. Output yaitu hasil produksi karyawan yang diperoleh sesuai produk yang diinginkan perusahaan.

\section{Pengertian Motivasi Kerja}

Malayu P. Hasibuan (2003:143) menyatakan bahwa motivasi adalah pemberi daya penggerak yang menciptakan kegairahan kerja seseorang agar mereka mau bekerja sama, bekerja efektif dan terintegrasi dengan segala daya dan upaya untuk mencapai kepuasan.

$$
\text { Veithzal Rivai }
$$

menyatakan bahwa motivasi adalah serangkaian sikap dan nilai-nilai yang mempengaruhi individu untuk mencapai hal yang spesifik sesuai dengan tujuan individu. Sikap dan nilai tersebut merupakan suatu yang invisible yang memberikan kekuatan untuk mendorong individu bertingkah laku dalam mencapai tujuan.
Berdasarkan beberapa definisi dapat disimpulkan bahwa motivasi adalah suatu penggerak yang menciptakan kegairahan kerja seseorang untuk mencapai kepuasan dan mendorong individu untuk mencapai tujuan kebutuhan individunya seperti insentif, dengan indikator sebagai berikut:

1. Penggerak yang menciptakan kegairahan kerja seseorang untuk mendorong individu mencapai tujuan (Semangat kerja)

2 Mencapai kepuasan (Kepuasan)

3. Kebutuhan individual seperti insentif (Kebutuhan)

\section{Tujuan-tujuan Motivasi Kerja}

1. Meningkatkan moral dan kepuasan kerja karyawan.

2. Meningkatkan produktivitas kerja karyawan.

3. Mempertahankan kestabilan karyawan perusahaan.

4. Meningkatkan kedisiplinan karyawan.

5. Mengefektifkan pengadaan karyawan.

6. menciptakan suasana dan hubungan kerja yang baik.

7. Meningkatkan loyalitas, kreativitas dan partisipasi karyawan.

8. Meningkatkan tingkat kesejahteraan karyawan.

9. Mempertinggi rasa tanggung jawab karyawan terhadap tugas-tugasnya.

10. Meningkatkan efisiensi penggunaan alat-alat dan bahan baku.

\section{Faktor-faktor yang Mempengaruhi} Motivasi Kerja

1. Faktor Internal

- Prestasi

- Pengakuan

- Pekerjaan Itu Sendiri

- Tanggung Jawab

- Pengembangan Potensi Individu

2. Faktor Eksternal

- Gaji atau Upah

- Kondisi Kerja

- Kebijaksanaan dan Administrasi Perusahaan

- Hubungan antar Pribadi 


\section{Pengertian Loyalitas Kerja}

Fathoni (2006:122) menyatakan

bahwa loyalitas kerja adalah usaha karyawan dalam membela perusahaan, dengan menunjukan bahwa karyawan tersebut berperan aktif terhadap perusahaannya.

Secara umum loyalitas dapat diartikan sebagai kesetian, pengabdian dan kepercayaan yang diberikan atau ditujukan kepada seseorang atau lembaga yang didalamnya terdapat rasa cinta dan tanggung jawab untuk berusaha memberikan pelayanan dan perilaku terbaik (Rasimin 2001:61).

Berdasarkan definisi di atas dapat disimpulkan bahwa loyalitas kerja adalah sebagai sikap dan perilaku karyawan dalam membela perusahaan yang berperan aktif dan bertanggung jawab terhadap perusahaan serta kesetian karyawan yang menempatkan kepentingan perusahaan di atas kepentingannya, pengabdian dan kepercayaan yang diberikan terhadap perusahaan untuk terus bekerja dan berusaha sebaik-baiknya, dengan indikator sebagai berikut:

1. Usaha karyawan dalam membela perusahaan dan berperan aktif terhadap perusahaan (Sikap dan Perilaku)

2. Pengabdian dan kepercayaan yang diberikan kepada lembaga (Kepercayaan)

3. Tanggung jawab, bekerja dan berusaha sebaik-baiknya terhadap perusahaan (Tanggung jawab)

4. Kesetiaan karyawan, dengan menempatkan kepentingan perusahaan diatas kepentingan pribadinya (Kesetiaan)

Faktor-faktor Meningkatkan Loyalitas Kerja

Terdapat beberapa faktor yang dapat meningkatkan loyalitas kerja sebagai berikut:

1. Meningkatkan hubungan yang erat antar karyawan

2. Saling terbuka dalam hubungan kerja
3. Saling pengertian antara pimpinan dan bawahan

4. Memperlakukan karyawan tidak sebagai buruh, tetapi sebagai mitra kerja

5. Pimpinan berusaha menyelami pribadi karyawan secara kekeluargaan

\section{Faktor-faktor Timbulnya Loyalitas Kerja}

Adapun timbulnya loyalitas kerja sebagai berikut:

- Karakteristik pribadi, meliputi: usia, masa kerja, tingkat pendidikan, prestasi yang dimiliki, ras, dan sifat kepribadian.

- Karakteristik pekerjaan, meliputi: tantangan kerja, stres kerja, kesempatan untuk berinteraksi sosial, job enrichment, identifikasi tugas, umpan balik tugas, dan kecocokan tugas.

- Karakteristik desain perusahaan, yang dapat dilihat dari sentralisasi, tingkat formalitas, tingkat keikutsertaan dalam pengambilan keputusan, menunjukkan sikap tanggungjawab terhadap perusahaan.

- Pengalaman yang diperoleh dalam perusahaan, yaitu internalisasi individu terhadap perusahaan setelah melaksanakan pekerjaan dalam perusahaan tersebut meliputi sikap positif terhadap perusahaan, rasa percaya terhadap perusahaan sehingga menimbulkan rasa aman, merasakan adanya kepuasan pribadi yang dapat dipenuhi oleh perusahaan

\section{Kerangka Teori}

Penelitian ini akan mengungkap pengaruh motivasi kerja dan loyalitas kerja karyawan terhadap produktivitas kerja karyawan pada PT. Cisarua Mountain Dairy. Responden yang diteliti adalah karyawan PT. Cimory sejumlah 500 karyawan. Dipredisikan motivasi kerja dan loyalitas kerja mempunyai pengaruh yang positif terhadap produktivitas kerja karyawan. 


\section{Gambar 1 \\ Kerangka Teori}

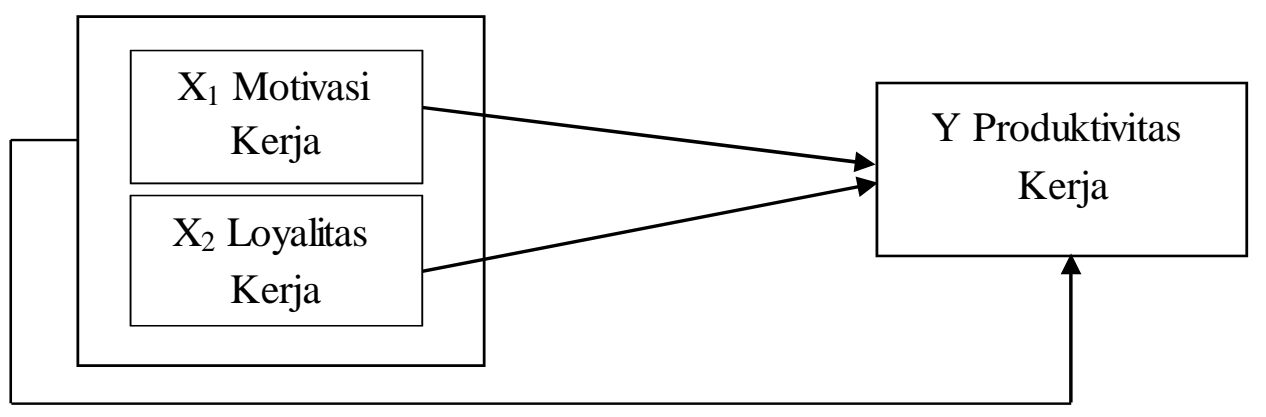

H1 : Diduga terdapat pengaruh positif motivasi kerja terhadap produktivitas kerja karyawan PT. Cimory.

$\mathrm{H} 2$ : Diduga terdapat pengaruh positif loyalitas kerja terhadap produktivitas kerja karyawan PT. Cimory.

H3 : Diduga motivasi kerja dan loyalitas kerja secara simultan berpengaruh positif terhadap produktivitas kerja karyawan PT. Cimory.

\section{Model Penelitian}

Model penelitian adalah kuantitatif, kuantitatif adalah suatu proses menemukan pengetahuan yang menggunakan angka sebagai alat menemukan keterangan mengenai apa yang ingin kita ketahui.

Menurut Sugiyono (2012:7) metode penelitian kuantitatif dapat diartikan sebagai metode penelitian yang berlandaskan pada filsafat positivisme, digunakan untuk meneliti pada populasi atau sampel tertentu.

\section{Populasi dan Sampel}

Populasi yang digunakan dalam penelitian ini adalah karyawan PT. Cisarua Mountain Dairy pada tahun 2019 yang akan diambil sebanyak 500 orang. Dalam penelitian ini pengambilan sampel menggunakan teknik Simpel Random Sampling. Jumlah sampel dalam penelitian ini ditentukan berdasarkan rumus slovin dengan taraf kepercayaan $90 \%$ (taraf signifikan 0,10). Rumus slovin dengan taraf kepercayaan $90 \%$ (taraf signifikan $0,10)$ adalah sebagai berikut:

$$
\mathrm{n}=\frac{\mathrm{N}}{1+\mathrm{N}(\mathrm{e}) 2}
$$

Di mana:

n : Ukuran sampel

$\mathrm{N}$ : Ukuran populasi

e : Nilai kritis

$$
\mathrm{n}=\frac{500}{1+500(0,01) 2}=99,8=100
$$

Berdasarkan penghitungan pengambilan sampel di atas, maka dapat diketahui bahwa jumlah sampel yang digunakan dalam penelitian ini adalah sebanyak 100 (seratus) responden pada karyawan PT. Cimory.

\section{$7 \quad$ Teknik Pengumpulan Data}

Teknik Pengumpulan data dalam penelitian ini menggunakan wawancara dan kuesioner.

\section{Instrumen Penelitian}

Pada penelitian ini instrumen yang digunakan yaitu kuesioner yang berisi beberapa pertanyaan untuk diisi oleh responden atau karyawan PT. Cisarua Mountain Dairy. Dalam penelitian ini peneliti menggunakan kuesioner/angket tertutup, di mana responden hanya memilih jawaban yang tersedia. Skala pengukuran yang digunakan dalam instrumen ini adalah skala likert.

\section{Teknik Analisa Data}

Penelitian dibantu dengan program SPSS versi 23.00 dengan alat analisis:
1. Uji Validitas 
2. Uji Realibilitas

3. Teknik Analisis Deskriptif

4. Uji Asumsi Klasik

5. Uji Regresi Berganda

6. Uji Kelayakan Suatu Model

\section{Hasil Penelitian}

a. Uji Validitas

Untuk melakukan pengujian validitas digunakan SPSS 23.0 dengan taraf signifikan sebesar 5\%. Dari 100 orang responden yang menjadi sampel maka perhitungan $\mathrm{r}$ tabel adalah sebagai berikut:

$$
\begin{aligned}
& \text { df }=N-2 \\
& \text { df }=100-2 \\
& \text { df }=98
\end{aligned}
$$

Teknik ini membandingkan nilai rhitung dengan rtabel, rtabel dicari pada signifikansi 0,1 dengan uji 2 sisi dan jumlah data $(\mathrm{n})=100$, df $=\mathrm{n}-2$ maka didapat $\mathrm{r}$-tabel sebesar 0,195.

Tabel 1

Hasil Uji Validitas Motivasi Kerja

\begin{tabular}{|c|c|c|c|c|}
\hline Dimensi & Variabel & $\begin{array}{c}\text { Nilai r- } \\
\text { hitung }\end{array}$ & Nilai r-tabel & Keterangan \\
\hline \multirow{3}{*}{$\begin{array}{c}\text { Semangat } \\
\text { Kerja }\end{array}$} & $\mathrm{X} 1.1$ & 0,388 & 0,195 & Valid \\
\cline { 2 - 5 } & $\mathrm{X} 1.2$ & 0,382 & 0,195 & Valid \\
\cline { 2 - 5 } & $\mathrm{X} 1.3$ & 0,560 & 0,195 & Valid \\
\hline \multirow{4}{*}{ Kepuasan } & $\mathrm{X} 1.4$ & 0,377 & 0,195 & Valid \\
\cline { 2 - 5 } & $\mathrm{X} 1.5$ & 0,380 & 0,195 & Valid \\
\cline { 2 - 5 } & $\mathrm{X} 1.6$ & 0,423 & 0,195 & Valid \\
\cline { 2 - 5 } & $\mathrm{X} 1.7$ & 0,364 & 0,195 & Valid \\
\hline \multirow{3}{*}{ Kebutuhan } & $\mathrm{X} 1.8$ & 0,568 & 0,195 & Valid \\
\cline { 2 - 5 } & $\mathrm{X} 1.9$ & 0,438 & 0,195 & Valid \\
\cline { 2 - 5 } & $\mathrm{X} 1.10$ & 0,417 & 0,195 & Valid \\
\hline
\end{tabular}

Sumber: Hasil olah data SPSS 23.0, 2020

Tabel 2

Hasil Uji Validitas Loyalitas Kerja

\begin{tabular}{|c|c|c|c|c|}
\hline Dimensi & Variabel & $\begin{array}{c}\text { Nilai r- } \\
\text { hitung }\end{array}$ & Nilai r-tabel & Keterangan \\
\hline \multirow{3}{*}{$\begin{array}{c}\text { Sikap dan } \\
\text { Perilaku }\end{array}$} & $\mathrm{X} 2.1$ & 0,289 & 0,195 & Valid \\
\cline { 2 - 5 } & $\mathrm{X} 2.2$ & 0,383 & 0,195 & Valid \\
\cline { 2 - 5 } & $\mathrm{X} 2.3$ & 0,411 & 0,195 & Valid \\
\hline \multirow{3}{*}{$\begin{array}{c}\text { Tanggung } \\
\text { Jawab }\end{array}$} & $\mathrm{X} 2.4$ & 0,421 & 0,195 & Valid \\
\cline { 2 - 5 } & $\mathrm{X} 2.5$ & 0,525 & 0,195 & Valid \\
\cline { 2 - 5 } & $\mathrm{X} 2.6$ & 0,260 & 0,195 & Valid \\
\hline \multirow{2}{*}{ Kesetiaan } & $\mathrm{X} 2.7$ & 0,370 & 0,195 & Valid \\
\cline { 2 - 5 } & $\mathrm{X} 2.8$ & 0,362 & 0,195 & Valid \\
\hline \multirow{2}{*}{ Kepercayaan } & $\mathrm{X} 2.9$ & 0,559 & 0,195 & Valid \\
\cline { 2 - 5 } & $\mathrm{X} 2.10$ & 0,480 & 0,195 & Valid \\
\hline
\end{tabular}

Sumber: Hasil olah data SPSS 23.0, 2020 
Tabel 3

Hasil Uji Validitas Produktivitas Kerja

\begin{tabular}{|c|c|c|c|c|}
\hline Dimensi & Variabel & $\begin{array}{c}\text { Nilai r- } \\
\text { hitung }\end{array}$ & Nilai r-tabel & Keterangan \\
\hline \multirow{3}{*}{ Kemampuan } & Y.1 & 0,418 & 0,195 & Valid \\
\cline { 2 - 5 } & Y.2 & 0,558 & 0,195 & Valid \\
\cline { 2 - 5 } & Y.3 & 0,368 & 0,195 & Valid \\
\hline \multirow{2}{*}{ Kualitas/Mutu } & Y.4 & 0,217 & 0,195 & Valid \\
\cline { 2 - 5 } & Y.5 & 0,392 & 0,195 & Valid \\
\hline \multirow{2}{*}{ SDM } & Y.6 & 0,525 & 0,195 & Valid \\
\cline { 2 - 5 } & Y.7 & 0,468 & 0,195 & Valid \\
\hline \multirow{3}{*}{ Efisiensi } & Y.8 & 0,495 & 0,195 & Valid \\
\cline { 2 - 5 } & Y.9 & 0,583 & 0,195 & Valid \\
\cline { 2 - 5 } & Y.10 & 0,335 & 0,195 & Valid \\
\hline
\end{tabular}

Sumber: Hasil olah data SPSS 23.0, 2020

\section{b. Uji Reliabilitas}

Reliabilitas merupakan ukuran suatu kestabilan dan konsistensi responden dalam menjawab hal yang berkaitan dengan konstruk-konstruk pertanyaan yang merupakan dimensi suatu variabel dan disusun dalam suatu bentuk kuesioner.
Kategori koefisien reliabilitas (Guilford, 1956: 145) adalah sebagai berikut:

- $0,80<$ r11 1,00 reliabilitas sangat tinggi

- $0,60<$ r11 0,80 reliabilitas tinggi

- $0,40<$ r11 0,60 reliabilitas sedang

- $0,20<$ r11 0,40 reliabilitas rendah.

- $-1,00$ r11 0,20 reliabilitas sangat rendah (tidak reliable)

Tabel 4

Hasil Uji Realibilitas

\begin{tabular}{|c|c|c|}
\hline Variabel & Reliabilitas & Keterangan \\
\hline Motivasi (X1) & 0,502 & Reliable Sedang \\
\hline Loyalitas (X2) & 0,431 & Reliable Sedang \\
\hline Produktivitas (Y) & 0,526 & Reliable Sedang \\
\hline
\end{tabular}

Sumber: Hasil olah data SPSS 23.0, 2020

\section{c. Uji Asumsi Klasik}

\section{Uji Normalitas}

Untuk mendeteksi normalitas dapat menggunakan analisis grafik melalui grafik normal P-P Plot. Normal atau tidaknya data dapat dilihat dengan dasar pengambilan keputusan sebagai berikut:
- model regresi tersebut berdistribusi normal, karena terlihat dari data menyebar sekitar garis diagonal dan mengikuti arah diagonal, maka model regresi memenuhi asumsi normalitas. 
Gambar 2

Hasil Uji Normalitas

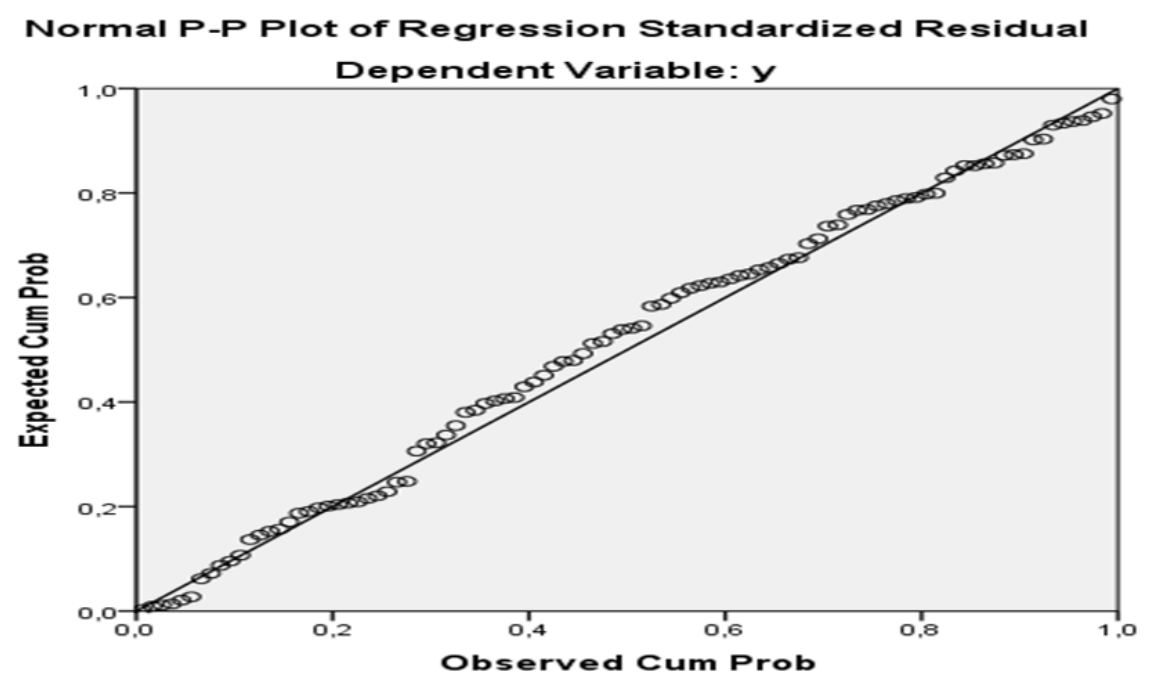

\section{Multikolineritas}

Berdasarkan output SPSS 23 dapat

diketahui bahwa nilai tolerance dari variabel motivasi dan loyalitas kerja karyawan adalah 0,996 lebih dari 0,10 dan nilai VIF adalah 1,004 kurang dari 10, maka dapat disimpulkan bahwa dalam model regresi tidak terjadi multikolineritas.

\section{Heteroskesdastisitas}

Untuk mendeteksi ada tidaknya heteroskedastisitas yaitu dengan melihat scatterplot. Jika tidak ada pola yang jelas (bergelombang, melebar kemudian menyempit) pada gambar scatterplot, serta titik-titik menyebar di atas dan di bawah angka 0 pada sumbu Y, maka dapat disimpulkan bahwa tidak terjadi heteroskedastisitas pada model regresi.

\section{Gambar 3 \\ Scatterplot}

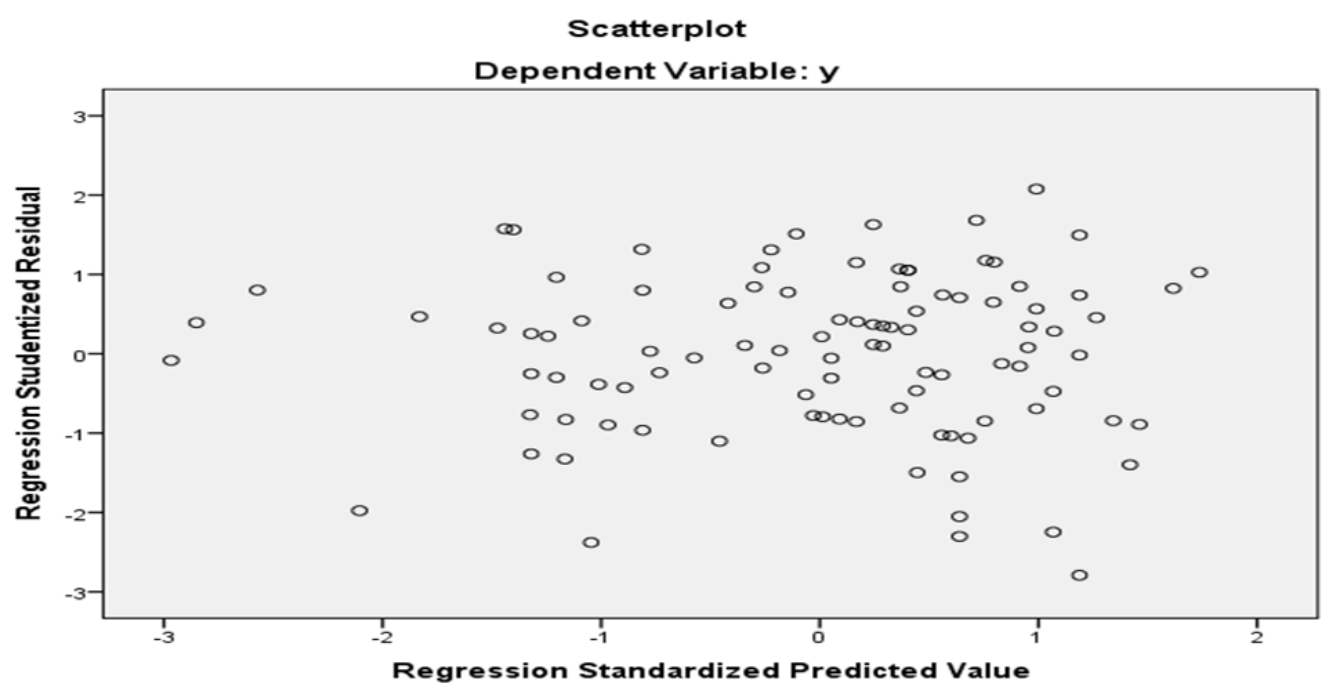


Tabel 5

Hasil Uji Autokolerasi

\begin{tabular}{|r|r|r|r|r|r|r|}
\hline \multirow{2}{*}{ Model } & \multicolumn{5}{|c|}{ Change Statistics } & \multirow{2}{*}{$\begin{array}{l}\text { Durbin- } \\
\text { Watson }\end{array}$} \\
\cline { 2 - 6 } & $\begin{array}{c}\text { R Square } \\
\text { Change }\end{array}$ & $\begin{array}{c}\text { F } \\
\text { Change }\end{array}$ & df1 & df2 & $\begin{array}{c}\text { Sig. F } \\
\text { Change }\end{array}$ & Wats \\
\hline 1 & 0,143 & 8,108 & 2 & 97 & 0,001 & 1,143 \\
\hline
\end{tabular}

Sumber: Hasil olah data SPSS 23.0, 2020

Berdasarkan tabel di atas nilai DurbinDi mana $Y=16,136+0,446+0,063$

Watson adalah sebesar 1.143, jika dibandingkan dengan nilai tabel D-W dalam model ini terdapat masalah autokolerasi karena nilainya jauh di bawah nilai tabel D-W yaitu dL 1,633 dan Du 1,715 .

\section{Uji Regresi Berganda}

Berdasarkan output SPSS 23 menjelaskan bahwa nilai dari Coefficients konstanta yaitu 16,136, sedangkan nilai dari motivasi (X1) 0,446 dan nilai dari variabel loyalitas (X2) 0,063.

\section{d. Uji Kelayakan Suatu Model Uji Statistik f}

Berdasarkan tabel $\mathrm{F}$ dengan nilai df $1=1$ dan df $2=97$ maka nilai $F$ tabelnya adalah 3,09. Dari hasil regresi output SPSS 23 dapat dilihat bahwa nilai $f$ hitung $(8,108)$, sehingga dapat disimpulkan bahwa variabel bebas (motivasi kerja X1, loyalitas kerja X2) secara simultan berpengaruh signifikan terhadap variabel terikat (produktivitas $\mathrm{Y}$ ).

Tabel 6

Hasil Uji Statistik f ANOVAa

\begin{tabular}{|r|l|r|r|r|c|c|}
\hline \multicolumn{2}{|l|}{ Model } & \multicolumn{1}{|c|}{$\begin{array}{l}\text { Sum of } \\
\text { Squares }\end{array}$} & \multicolumn{1}{c|}{ Df } & Mean Square & F & \multicolumn{1}{c|}{ Sig. } \\
\hline \multirow{2}{*}{1} & Regression & 261,538 & 2 & 130,769 & 8,108 &, $001^{\text {b }}$ \\
& Residual & 1564,5 & 97 & 16,129 & & \\
& Total & 1826,04 & 99 & & & \\
\hline
\end{tabular}

Sumber: Hasil olah data SPSS 23.0, 2020

\section{Uji Statistik t}

Berdasarkan output SPSS 23 dengan jumlah $\mathrm{n}=100$ maka nilai t tabel adalah $\mathrm{n}$ $1=\mathrm{df}-1=99$, nilai $\mathrm{t}$ tabelnya adalah 1,660, dapat disimpulkan sebagai berikut:

- Variabel X1 (motivasi kerja) memiliki nilai $\mathrm{t}$ hitung 4,021>t tabel 1,660, artinya variabel bebas $\mathrm{X} 1$ (motivasi kerja) berpengaruh terhadap variabel terikat Y (produktivitas kerja).

- Variabel X2 (loyalitas kerja) memiliki nilai $\mathrm{t}$ hitung $0,462<\mathrm{t}$ tabel 1,660, artinya variabel bebas X2 (loyalitas kerja) tidak berpengaruh terhadap variabel terikat $\mathrm{Y}$ (produktivitas kerja). 
Tabel 7

Hasil Uji Statistik $t$

\begin{tabular}{|r|r|r|r|r|r|r|}
\hline \multirow{2}{*}{ Model } & \multicolumn{2}{|c|}{$\begin{array}{c}\text { Unstandardized } \\
\text { Coefficients }\end{array}$} & $\begin{array}{c}\text { Standardized } \\
\text { Coefficients }\end{array}$ & \multirow{2}{*}{$\mathrm{T}$} & \multirow{2}{*}{ Sig. } \\
\cline { 3 - 4 } \multicolumn{2}{|c|}{} & \multicolumn{1}{|c|}{ B } & Std. Error & \multicolumn{1}{c|}{ Beta } & & \\
\hline \multirow{3}{*}{1} & (Constant) & 16,136 & 5,974 & & 2,701 & 0,008 \\
& X1 Motivasi & 0,446 & 0,111 & 0,379 & 4,021 & 0 \\
& X2 Loyalitas & 0,063 & 0,136 & 0,043 & 0,462 & 0,645 \\
\hline
\end{tabular}

Sumber: Hasil olah data SPSS 23.0, 2020

Area tidak

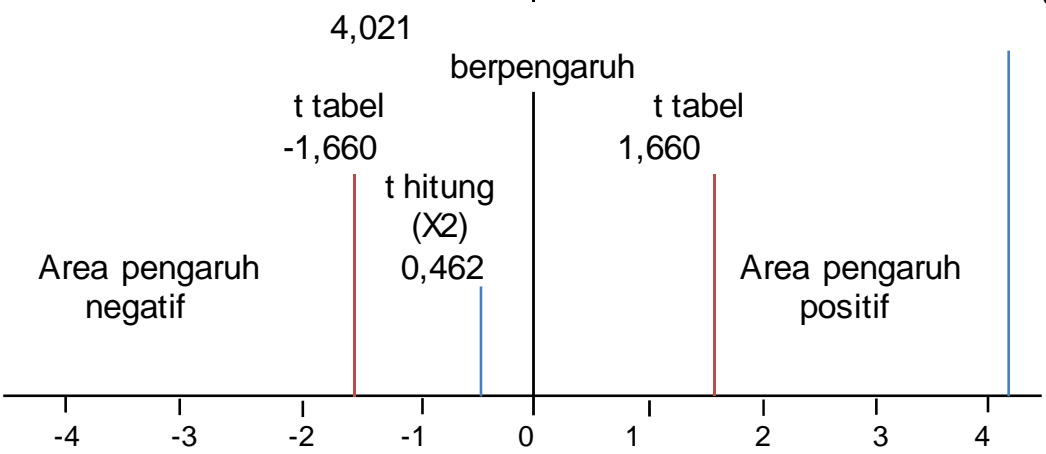

Uji Determinasi $\left(\mathbf{R}^{2}\right)$

Berdasarkan output SPSS 23, diperoleh angka R2 (R Square) sebesar 0,126 atau $13 \%$, hal ini berarti presentase pengaruh variabel bebas (motivasi dan loyalitas) terhadap variabel terikat
Gambar 4

Kurva Uji Statistik t

t hitung $(X 1)$

Tabel 8

Hasil Uji Determinasi $\left(\mathbf{R}^{\mathbf{2}}\right)$

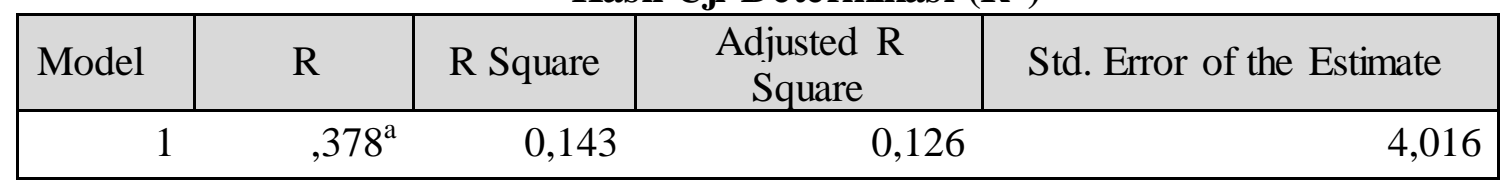

Sumber: Hasil olah data SPSS 23.0, 2020

11. Kesimpulan

Berdasarkan hasil penelitian ini, penulis menyimpulkan:

1. Berdasarkan hasil uji t, motivasi kerja berpengaruh terhadap produktivitas kerja dapat diketahui dari hasil (produktivitas) adalah $13 \%$ dipengaruhi oleh variabel yang diteliti dalam penelitian ini. Dengan nilai $\mathrm{R}$ square dikatakan baik jika di atas 0,5 karena nilai $R$ square berkisar antara $0-1$. 
agar karyawan bekerja lebih giat dalam mengerjakan pekerjaan, sehingga dapat mempengaruhi produktivitas kerja karyawan.

2. Berdasarkan hasil uji t, loyalitas kerja tidak berpengaruh terhadap produktivitas kerja dapat diketahui dari hasil t hitung 0,462 < 1,660 t tabel. Hal ini disebabkan kurangnya kepercayaan karyawan terhadap perusahaan akan memberikan feedback yang baik. Hasil ini membuktikan bahwa kekuatan yang memotivasi karyawan untuk bekerja lebih giat dalam mengerjakan pekerjaan tergantung pada hubungan timbal balik antara apa yang diinginkan dan dibutuhkan dari hasil pekerjaan itu, sehingga dapat timbul sikap loyalitas karyawan terhadap perusahaan yang dapat meningkatkan produktivitas kerja karyawan.

3. Berdasarkan hasil uji f, ditemukan motivasi kerja dan loyalitas kerja secara bersama-sama berpengaruh signifikan terhadap produktivitas kerja. Hal ini dibuktikan dengan uji $\mathrm{f}$ yang menghasilkan nila $f$ hitung sebesar 8,108 lebih besar dari nilai $\mathrm{f}$ tabel sebesar 3.09. Artinya motivasi kerja dan loyalitas kerja secara bersama-sama berpengaruh terhadap produktivitas kerja karyawan.

\section{Saran}

1. Bagi perusahaan

Berdasarkan distribusi jawaban responden melalui kuesioner yang telah dibagikan kepada karyawan PT. Cimory mengenai motivasi kerja, loyalitas kerja dan produktivitas kerja, maka dapat diketahui bahwa karyawan sudah bekerja sesuai dengan standar perusahaan. Untuk itu, ada baiknya perusahaan menjaga dan meningkatkan apa yang sudah perusahaan jalankan selama ini agar semua dapat berjalan dengan baik dan bisa memberikan timbal balik yang baik pula terhadap perusahaan.

2. Bagi peneliti selanjutnya

Untuk penelitian selanjutnya, ada baiknya untuk menambah variabel yang kurang dalam penelitian ini, agar penelitian yang dilakukan akan terlihat lebih menarik. 


\section{DAFTAR PUSTAKA}

Hasibuan, Malayu S.P. (2003)

Manajemen Sumber Daya

Manusia.

Ravianto. (1986). Pengukuran Produktivitas. Yogyakarta:

Kanisius.

Malayu S.P hasibuan. (2004). Organisasi dan Motivasi. Jakarta: PT. Bumi Aksara. Ketujuh. Jakarta: PT. Bumi Aksara.

Rivai, Veithzal dan Ella Jauvani Sagala. (2011). Manajemen Sumber Daya Manusia untuk Perusahaan. Jakarta: Rajawali Pers.

Sutrisno, Edy. (2010). Manajemen Sumber Daya Manusia.

Jakarta: Kencana 